\title{
Preliminary Study About A Significant and Treatable Cause of Epileptic Encephalopathy: GRIN2D Mutation
}

\section{Epileptik Ensefalopatinin Önemli ve Tedavi Edilebilir Bir Nedeni Hakkında Ön Çalışma: GRIN2D Mutasyonu}

\author{
Muhammet Gultekin Kutluk ${ }^{*}$, Nadide Cemre Randa ${ }^{2}$
}

1.Antalya Research and Training Hospital, Department of Paediatric Neurology, Antalya, Turkey

2.Antalya Research and Training Hospital, Department of Medical Genetics, Antalya, Turkey.

\section{ABSTRACT}

Aim: The GRIN2D gene mutation causes severe forms of epileptic encephalopathy. NMDAR antagonists and magnesium sulfate could be useful as adjunctive therapy to control seizures in individuals with GRIN2D encephalopathy. The aim of this study was to describe the clinical features and treatment options of GRIN2D encephalopathy. Methods: Patients followed up with epileptic encephalopathy in our pediatric neurology clinic were investigated for genetic etiology using next-generation sequencing (NGS)-based tests. Patients with the GRIN2D mutation were overviewed for clinical and genetic characteristics.

Results: A total of 53 patients were screened and GRIN2D mutations (c.3684_3685insGA, c.3248_3254del, c.1579G $>$ T, c.47_49del) were detected in four patients. Occipital epileptic activity was frequently detected among our patients. Three patients received memantine treatment for intractable epilepsy and remained seizure-free.

Conclusion: GRIN2D encephalopathy is a treatable epileptic encephalopathy, and its recognition is important in terms of outcomes. Occipital epilepsy is generally benign, but developmental and epileptic encephalopathies such as GRIN2D encephalopathy should be considered in the presence of concomitant developmental delay.

Keywords: developmental delay; epileptic encephalopathy; GRIN2D; memantine; NMDA

\section{öz}

Amaç: GRIN2D gen mutasyonu, ağır epileptik ensefalopatiye neden olur. NMDAR antagonistleri ve magnezyum, GRIN2D ensefalopatili bireylerde nöbetleri kontrol etmek için faydalı bir tedavi seçeneği olabilir. Bu çalışmanın amacı GRIN2D ensefalopatisinin klinik özellikleri ile tedavi seçeneklerini tanımlamaktır.

Yöntemler: Çocuk nöroloji kliniğimizde epileptik ensefalopati ile izlenen hastalar genetik etiyoloji açısından yeni nesil dizileme yöntemi tabanlı testler ile incelendi. GRIN2D mutasyonu olan hastalar klinik ve genetik özellikler açısından değerlendirildi. Bulgular: Toplam 53 hasta tarandı. 4 hastada GRIN2D mutasyonlar (c.3684_3685insGA, c.3248_3254del, c.1579G>T, c.47_49del) tespit edildi. Hastalarımızda oksipital epileptik aktivite sıkı।kla tespit edildi. 3 hastaya inatçı epilepsi için memantin tedavisi başlandı ve bu hastalar nöbetsiz olarak takip edilmekteler. Sonuç: GRIN2D ensefalopati, tedavi edilebilir bir epileptik ensefalopatidir ve hastanın sağkalımı açısından tanınması önemlidir. Oksipital epilepsi genellikle iyi huyludur, ancak eşlik eden gelişimsel gecikme varlığında GRIN2D ensefalopatisi gibi gelişimsel ve epileptik ensefalopatiler akla gelmelidir.

Anahtar Sözcükler: epileptik ensefalopati, gelişme geriliği, GRIN2D, memantin NMDA

Received: 05.03.2021 Accepted:18.04.2021 Published (Online): 30.08.2021

*Corresponding Author: Muhammet Gultekin Kutluk, MD. Antalya Eğitim ve Araştırma Hastanesi, Varlık Bulvarı, Kazım Karabekir caddesi, 07100 Muratpaşa, Antalya/ Türkiye.+905326765982,gultekinkutluk@gmail.com

ORCID: 0000-0002-3631-068X

To cited: Kutluk MG, Randa NC. Preliminary Study About A Significant and Treatable Cause of Epileptic Encephalopathy: GRIN2D Mutation. Acta Med. Alanya 2021;5(2):109-117 doi:10.30565/medalanya.891938 


\section{INTRODUCTION}

(5) lutamate

is

the

main

excitatory

neurotransmitter of the central nervous system (CNS). Glutamate takes an important part in many basic neuronal functions and CNS processes, such as learning, memory, and synaptic plasticity. [1] N-methyl- D-aspartate receptors (NMDAR) are voltage-dependent ionotropic glutamate receptors and tetrameric assemblies containing GluN1 and GluN2 subunits. Four independent genes (GRIN2A, GRIN2B, GRIN2C, and GRIN2D) encode GluN2A-D subunits.[2] NMDAR activity is crucial for neurodevelopment, synaptogenesis, general cognition, spatial learning, locomotion, and memory formation. NMDAR mutations (GRIN1 [MIM: 138249], GRIN2A [MIM: 138253], GRIN2B [MIM: 138252], GRIN2C [MIM: 138254], and GRIN2D [MIM: 602717]) are associated with variable neurologic diseases, including schizophrenia, intellectual disabilities, autism, epilepsy, and attention-deficit/hyperactivity disorder.[3] Epileptic encephalopathies manifest with intractable seizures and neurodevelopmental disabilities and have monogenic disorders as part of the various etiologies. Children with epileptic encephalopathy have a shortened life expectancy, and most patients experience little to no relief from seizures with anti-epileptic drug (AED) treatment. In light of technological advances, genetic analysis has provided for establishing the precise genetic etiology in individuals.[4] Validation of genetic etiologies and specific disease mechanisms make personalized therapeutic regimens possible. Genetic variations of the autosomal dominant inherited GRIN2D gene mutation cause severe forms of epileptic encephalopathy, which manifest early during infantile or adolescent development. NMDAR mutations cause greatly increased current flow through mutant-GluN2A-containing NMDARs, leading to the excessive excitatory drive, thereby inducing seizure activity and/or excitotoxicity.[5] Memantine is a noncompetitive antagonist of the NMDA-type glutamate receptor. It interacts with the $\mathrm{Mg}+2$ binding site of the channel to prevent excessive activation while sparing normal function.[6] NMDAR antagonists and magnesium sulfate might be useful adjunctive therapy to control seizures in individuals with GRIN2D encephalopathy.[4] Here, we report distinct clinical, genomic, and therapeutic features of four patients with GRIN2D encephalopathy with different variants of the GRIN2D gene.

\section{METHODS}

Patients who were followed up with epileptic encephalopathy in the pediatric neurology clinic of Antalya Training and Research Hospital and had a genetic diagnosis were retrospectively screened. The genetic diagnosis was made by investigating the most common actionable genes of epileptic encephalopathy using next-generation sequencing (NGS)-based tests (Table 1).[7] Each variant was evaluated according to the American College of Medical Genetics and Genomics (ACMG) criteria. [8] The information about genetic examinations of the patients was given in details in the cases section.

Epileptic encephalopathy is defined as an electroclinical syndrome associated with a high probability of encephalopathic features that present or worsen after the onset of epilepsy by the International League Against Epilepsy (ILAE) Commission on Classification and Terminology.[9]

The aim of this study was to describe the clinical features and treatment options of GRIN2D encephalopathy. Electroencephalography (EEG), magnetic resonance imaging (MRI), and metabolic screening tests were performed for all patients with GRIN2D mutations. Only the clinical and genetic characteristics of patients with GRIN2D encephalopathy were reviewed and presented in this study. Written informed consent was obtained from all parents of the children, which was approved by Antalya Research and Training Hospital Ethics Committee (Date: 04.03.2021 number: 1/44).

\section{RESULTS}

Patients:

A total of 53 patients with epileptic encephalopathy were screened using NGS-based tests. A genetic mutation associated with epileptic encephalopathy was detected in 33 patients $(62,2 \%)$. Novel variants in GRIN2D were detected in four patients $(7,5 \%)$ and none of these variants was reported in the literature before. By using the ACMG criteria, we classified GRIN2D variants as pathogenic or likely pathogenic. The clinical and genetic 
characteristics and treatment regimens of patients with GRIN2D encephalopathy which is rare and treatable are presented as case reports below.

\section{Case 1}

The first patient was a 3-year-old girl, who presented to our clinic with status epilepticus at age 2.5 years. She was previously followed with intractable epilepsy, global developmental delay, and static encephalopathy. Her prenatal period was uneventful, and she was born at term as the first child from nonconsanguineous parents. She had no previous neurologic medical history in her family. She had migratory focal clonic seizures in the first week of life. Later, hypotonia and eye flutter accompanied the seizures. Phenobarbital, levetiracetam, and topiramate were given for the seizures, respectively. She was unresponsive to treatment, had status epilepticus, and was admitted to the pediatric intensive care unit (PICU) at age 3 months. Her seizures were managed with midazolam and thiopental infusions. Carbamazepine and clonazepam were added to treatment instead of phenobarbital. She was admitted to the PICU three more times for status epilepticus until the age of 2 years. Valproic acid, lamotrigine, sulthiame, and clobazam were also added to treatment but she was unresponsive.

A physical examination revealed normal deep tendon reflexes, strabismus, bilateral ocular flutter, truncal ataxia, and mild hypotonia. She had no dysmorphic features or pathologic reflexes. She was able to hold her head at the age of 8 months and sit unsupported at the age of 14 months. She could not walk or talk.

The patient's first EEG showed multifocal epileptic anomaly and remained similar until the age of 1 year. Metabolic studies: ammonia, plasma, and urine amino acid analysis, long-chained fatty acid analysis, urine organic acid analysis, lactate, pyruvate, tandem mass spectrometry, vitamin B12, and folic acid were within normal limits. Her brain MRI and MR spectroscopy were normal.

At age 2.5 years, she had status epilepticus and was admitted to the PICU, when we first evaluated her for a pediatric neurology consultation. Her recent treatment regimen was valproic acid, lamotrigine, sulthiame, and clobazam. Her seizures continued as a multifocal clonic type while she was receiving midazolam and thiopental infusions. An EEG study during status epilepticus showed ictal epileptic discharges in the bilateral parietooccipital region. Ketamine infusion was initiated, and her seizures stopped. The second EEG study after the ketamine infusion showed interictal parietooccipital epileptic activity. Clinical exome sequencing (CES) was conducted after the ketamine response. A novel, heterozygous GRIN2D c.3684_3685insGA variant was detected. A GRIN2D c.3684_3685insGA (NM_000836.4, p.Pro1229AspfsTer290T) variant was evaluated according to the ACMG criteria, and this variant was classified as pathogenic because it was a null variant (frame-shift) and in gene GRIN2D, for which loss-of-function is a known mechanism of disease (gnomAD Loss-of-Function Observed/ Expected $=0.0529$ is less than 0.763 ), associated with developmental and epileptic encephalopathy 46 (PVS1 criteria), not found in gnomAD genomes (PM2 criteria), compatible with the patient's clinic (PP4 criteria). Oral memantine $(0.5 \mathrm{mg} / \mathrm{kg} / \mathrm{day})$ and magnesium sulfate therapies were initiated. Her seizure frequency and severity reduced gradually. In the last visit, the patient was seizurefree for 4 months, could continue her daily life, and her neuromotor development was improved. The latest EEG study was normal (Figure 1). She has been able to walk and talk with simple words since the age of 33 months (Table 2).

\section{Case 2}

Patient 2 was a 4.5-year-old girl who presented with neonatal seizures. Her prenatal period was uneventful, and she was born at term as the second child from nonconsanguineous parents. She had no previous neurologic medical history in her family. Her first seizure was focal onset motor clonic type on the 16th day of life. The first EEG study was normal. She was seizure-free for 2 months after phenobarbital therapy. She had flexor spasm seizures at 3 months, and the EEG study revealed hypsarrythmia. Adrenocorticotropic hormone (ACTH) and pyridoxine treatments were initiated and levetiracetam was added to treatment later. She had neuromotor developmental delay; she was able to raise her head at age 9 months and sit unsupported at the age of 26 months. She could not walk or talk. 
Table 1. List of actionable genes

\begin{tabular}{|c|c|c|}
\hline Actionable genes & $\begin{array}{l}\text { HGNC } \\
\text { Approved } \\
\text { Gene Symbol }\end{array}$ & $\begin{array}{l}\text { Phenotypes \#MIM } \\
\text { number }\end{array}$ \\
\hline Alpha-2B-Adrenergic Receptor & $A D R A 2 B$ & 607876 \\
\hline $\begin{array}{l}\text { Aldehyde Dehydrogenase } 7 \text { Family, } \\
\text { Member A1 }\end{array}$ & $A L D H 7 A 1$ & 266100 \\
\hline Folate Receptor, Alpha & FOLR1 & 613068 \\
\hline Guanidinoacetate Methyltransferase & GAMT & 612736 \\
\hline $\begin{array}{l}\text { L-Arginine:Glycine } \\
\text { Amidinotransferase }\end{array}$ & GATM & 612718,134600 \\
\hline $\begin{array}{l}\text { Potassium Channel, Voltage-gated, } \\
\text { Kqt-Like Subfamily, Member } 2\end{array}$ & KCNQ2 & 613720,121200 \\
\hline $\begin{array}{l}\text { Potassium Channel, Voltage-Gated, } \\
\text { Kqt-Like Subfamily, Member } 3 \\
\end{array}$ & KCNQ3 & 121201 \\
\hline $\begin{array}{l}\text { Potassium Channel, Subfamily T, } \\
\text { Member } 1\end{array}$ & KCNT1 & 614959,615005 \\
\hline Methyl-Cpg-binding Protein 2 & MECP2 & $\begin{array}{l}300496,300673, \\
300260,300055,312750\end{array}$ \\
\hline $\begin{array}{l}\text { Pyridoxamine 5-Prime-Phosphate } \\
\text { Oxidase }\end{array}$ & PNPO & 610090 \\
\hline Polymerase, DNA, Gamma & $P O L G$ & $\begin{array}{l}203700,613662, \\
607459,157640,258450\end{array}$ \\
\hline $\begin{array}{l}\text { Proline-Rich Transmembrane Protein } \\
2\end{array}$ & PRRT2 & $602066,128200,605751$ \\
\hline Quinoid Dihydropteridine Reductase & $Q D P R$ & 261630 \\
\hline $\begin{array}{l}\text { Sodium Voltage-gated Channel, } \\
\text { Alpha Subunit } 1\end{array}$ & SCN1A & $607208,604403,609634$ \\
\hline $\begin{array}{l}\text { Sodium Voltage-gated Channel, } \\
\text { Alpha Subunit } 2 \\
\end{array}$ & $S C N 2 A$ & $613721,618924,607745$ \\
\hline $\begin{array}{l}\text { Sodium Voltage-gated Channel, } \\
\text { Alpha Subunit } 8 \\
\end{array}$ & $S C N 8 A$ & $\begin{array}{l}618364,614306, \\
614558,617080 \\
\end{array}$ \\
\hline $\begin{array}{l}\text { Solute Carrier Family } 19 \text { (Thiamine } \\
\text { Transporter), Member } 3 \\
\end{array}$ & SLC19A3 & 607483 \\
\hline $\begin{array}{l}\text { Solute Carrier Family } 2 \text { (Facilitated } \\
\text { Glucose Transporter), Member } 1 \\
\end{array}$ & $S L C 2 A 1$ & $\begin{array}{l}614847,606777, \\
612126,608885 \\
\end{array}$ \\
\hline $\begin{array}{l}\text { Solute Carrier Family } 6 \\
\text { (Neurotransmitter Transporter, } \\
\text { Creatine), Member } 8\end{array}$ & SLC6A8 & 300352 \\
\hline Syntaxin-binding Protein 1 & STXBP1 & 612164 \\
\hline Tsc Complex Subunit 1 & TSC1 & $607341,606690,191100$ \\
\hline Tsc Complex Subunit 2 & TSC2 & $607341,606690,613254$ \\
\hline $\begin{array}{l}\text { Glutamate Receptor, Ionotropic, } \\
\text { N-Methyl-D-Aspartate, Subunit 2A }\end{array}$ & GRIN2A & 245570 \\
\hline Pyridoxal Phosphate-binding Protein & $P L P B P$ & 617290 \\
\hline $\begin{array}{l}\text { Glutamate Receptor, Ionotropic, } \\
\text { N-Methyl-D-Aspartate, Subunit 2D }\end{array}$ & GRIN2D & 617162 \\
\hline
\end{tabular}

The term "actionable genes" is used to indicate clinical applicability based on evidence and to describe the genes that are most effective in curing, preventing and/or delaying clinical disease. In our center, the "actionable genes" list includes genes that are statistically common and associated with specific FDA-approved drug response to help patients with epilepsy to receive appropriate treatment faster. These actionable genes were filtered out by Medical Genetics Department in our center.
Table 2. Phenotype and variant summary of GRIN2D encephalopathy patients. PVL: Periventricular leukomalacia, AEDs: antiepileptic drugs, LVT: levetiracetam, VPA: valproic acid, CBZ: carbamazepine,

\begin{tabular}{|c|c|c|c|c|}
\hline $\begin{array}{l}\text { Patient } \\
\text { number }\end{array}$ & 1 & 2 & 3 & 4 \\
\hline Age on-set & $1 \mathrm{wk}$ & 16 days & 4 years old & 16 days \\
\hline $\begin{array}{l}\text { Current Age } \\
\text { (years)/Sex }\end{array}$ & $3 / \mathrm{F}$ & $4 / F$ & $18 / \mathrm{M}$ & 7.5/M \\
\hline $\begin{array}{l}\text { GRIN2D } \\
\text { variants }\end{array}$ & $\begin{array}{l}\text { GRIN2D } \\
\text { c.3684_3685insGA }\end{array}$ & $\begin{array}{l}\text { GRIN2D } \\
\text { c.3248_ } \\
3254 \mathrm{del}\end{array}$ & $\begin{array}{l}\text { GRIN2D } \\
\text { c. } 1579 \mathrm{G}>\mathrm{T}\end{array}$ & $\begin{array}{l}\text { GRIN2D } \\
\text { c.47_49del }\end{array}$ \\
\hline EEG & $\begin{array}{l}\text { Parietooccipital } \\
\text { epileptic activity }\end{array}$ & \begin{tabular}{|l|} 
Parieto- \\
occipital \\
epileptic \\
activity \\
\end{tabular} & \begin{tabular}{|l|} 
Bilateral \\
temporal \\
epileptic \\
activity
\end{tabular} & $\begin{array}{l}\text { Bilateral } \\
\text { temporoparietal } \\
\text { epileptic activity }\end{array}$ \\
\hline MRI & Normal & PVL & Normal & Normal \\
\hline $\begin{array}{l}\text { Response to } \\
\text { AEDs }\end{array}$ & $\begin{array}{l}\text { No response to } \\
\text { other AEDs, } \\
\text { seizure-free with } \\
\text { memantine and } \\
\text { MgSO4 }\end{array}$ & $\begin{array}{l}\text { No response } \\
\text { to } L V T \text { and } \\
\text { VPA, seizure- } \\
\text { free with } \\
\text { memantine } \\
\end{array}$ & $\begin{array}{l}\text { Mild } \\
\text { response with } \\
\text { CBZ, LTG, } \\
\text { LVT and } \\
\text { memantine }\end{array}$ & $\begin{array}{l}\text { Seizure free with } \\
\text { VPA }\end{array}$ \\
\hline Age on-set & 1 week & 16 days & 4 years & 16 days \\
\hline $\begin{array}{l}\text { Develop- } \\
\text { mental delay } \\
\text { and other } \\
\text { neurological } \\
\text { features }\end{array}$ & $\begin{array}{l}\text { Hold her head } \\
\text { at } 8 \text { mo and sit } \\
\text { unsupported at } 14 \\
\text { mo. She can ataxic } \\
\text { walk and talk with } \\
\text { simple words since } \\
33 \text { mo. Occuler } \\
\text { flutter. }\end{array}$ & $\begin{array}{l}\text { Raise her } \\
\text { head at } \\
9 \text { mo, sit } \\
\text { unsupported } \\
\text { at } 26 \text { mo. } \\
\text { Cannot walk } \\
\text { or talk. Poor } \\
\text { attention to } \\
\text { surroundings, } \\
\text { strabismus, } \\
\text { hypertonicity, } \\
\text { hyperactive } \\
\text { deep tendon } \\
\text { reflexes. }\end{array}$ & $\begin{array}{l}\text { Mild mental } \\
\text { retardation }\end{array}$ & $\begin{array}{l}\text { Delayed speech } \\
\text { development }\end{array}$ \\
\hline
\end{tabular}

LTG: lamotrigine. 
In a physical examination, she had poor attention to surroundings, strabismus, hypertonicity, and hyperactive deep tendon reflexes. She had no dysmorphic features or pathologic reflexes.

Metabolic studies: ammonia, plasma, and urine amino acid analysis, long-chained fatty acid analysis, urine organic acid analysis, lactate, pyruvate, tandem mass spectrometry, vitamin B12, and folic acid were within normal limits. Brain MRI revealed periventricular leukomalacia and MR spectroscopy was normal. An epilepsy panel performed by using NGS analysis revealed a novel, heterozygous GRIN2D c.3248_3254del variant. The GRIN2D c.3248_3254del (NM_000836.4, p.Gly1083GlufsTer433) variant was evaluated according to the ACMG criteria, and this variant was classified as pathogenic because the variant is a null variant (frame-shift), and in gene GRIN2D, for which loss-of-function is a known mechanism of disease (gnomAD Loss-of-Function Observed/ Expected $=0.0529$ is less than 0.763 ), associated with developmental and epileptic encephalopathy 46 (PVS1 criteria), not found in gnomAD genomes (PM2 criteria), compatible with the patient's clinic (PP4 criteria). No other new therapies were initiated after the genetic analysis because her seizures had been under control with levetiracetam for 2 years, but follow-up EEG studies revealed parietooccipital epileptic activity. She had migratory focal clonic seizures and ocular flutter at the age of 3.5 years. Her seizures were prolonged and refractory, she had status epilepticus and was admitted to the PICU. Valproic acid was added to her antiepileptic treatment. An EEG study showed interictal epileptic activity in the parietooccipital region (Figure 2). On follow-up, her seizures continued as the multifocal clonic-type and ocular flutter. Memantine $(0.5 \mathrm{mg} / \mathrm{kg} /$ day $)$ was added to the treatment, seizures remained under control, and valproic acid and levetiracetam treatments were stopped gradually. She has been seizurefree for 8 months and the latest EEG was normal (Table 2).

\section{Case 3}

Patient 3 was an 18-year-old boy who was born at term to nonconsanguineous parents. His neonatal period was uneventful and his neuromotor development was appropriate, only his speech development was delayed. He presented for medical attention with a right focal motor clonic seizure following sudden visual loss at age 4 years. A EEG study showed bilateral occipital epileptic activity. Levetiracetam was initiated after the first seizure and oxcarbazepine was added to treatment later because of continuing multifocal clonic seizures. Multifocal clonic seizures and bilateral occipital epileptic activity remained for almost 4 years. At the age of 8 years, atonic seizures presented, and EEG studies showed bilateral temporal epileptic activity. Valproic acid, clobazam, carbamazepine, lamotrigine, rufinamide, lacosamide, sulthiame, primidone, zonisamide, topiramate were tried for treatment. Metabolic studies: ammonia, plasma, and urine amino acid analysis, long-chained fatty acid analysis, urine organic acid analysis, lactate, pyruvate, tandem mass spectrometry, vitamin B12, and folic acid were within normal limits. Brain MR and MR spectroscopy were normal. He presented to our clinic at around the age of 15 years. The only pathologic finding was mild mental retardation on physical examination. His intelligence quotient (IQ) score was 80 (IQ, Stanford Binet Intelligence Scales, 5th Edition). By that time, his seizure frequency was 4-5 times per week and the seizure types were atonic and multifocal clonic. On follow-up, his treatment was rearranged as carbamazepine, levetiracetam, and lamotrigine, and an EEG study showed bilateral frontotemporal epileptic activity. He was diagnosed as having non-Hodgkin lymphoma at the age of 16 years; therefore, he did not continue regular follow-ups for epilepsy for 1.5 years. After full remission of non-Hodgkin lymphoma, whole-exome sequencing (WES) analysis was performed and a novel, heterozygous GRIN2D c. $1579 \mathrm{G}>\mathrm{T}$ variant was detected. The GRIN2D c.1579G >T (NM_000836.4, p.Glu527Ter) variant was evaluated according to the ACMG criteria and classified as pathogenic because it was a null variant (frame-shift), and in gene GRIN2D, for which loss-of-function is a known mechanism of disease (gnomAD Loss-of-Function Observed/ Expected $=0.0529$ is less than 0.763 ), associated with developmental and epileptic encephalopathy 46 (PVS1 criteria), not found in gnomAD genomes (PM2 criteria), compatible with the patient's clinic (PP4 criteria). Memantine $(0.5 \mathrm{mg} / \mathrm{kg} / \mathrm{day})$ was initiated. The latest EEG study showed bilateral 


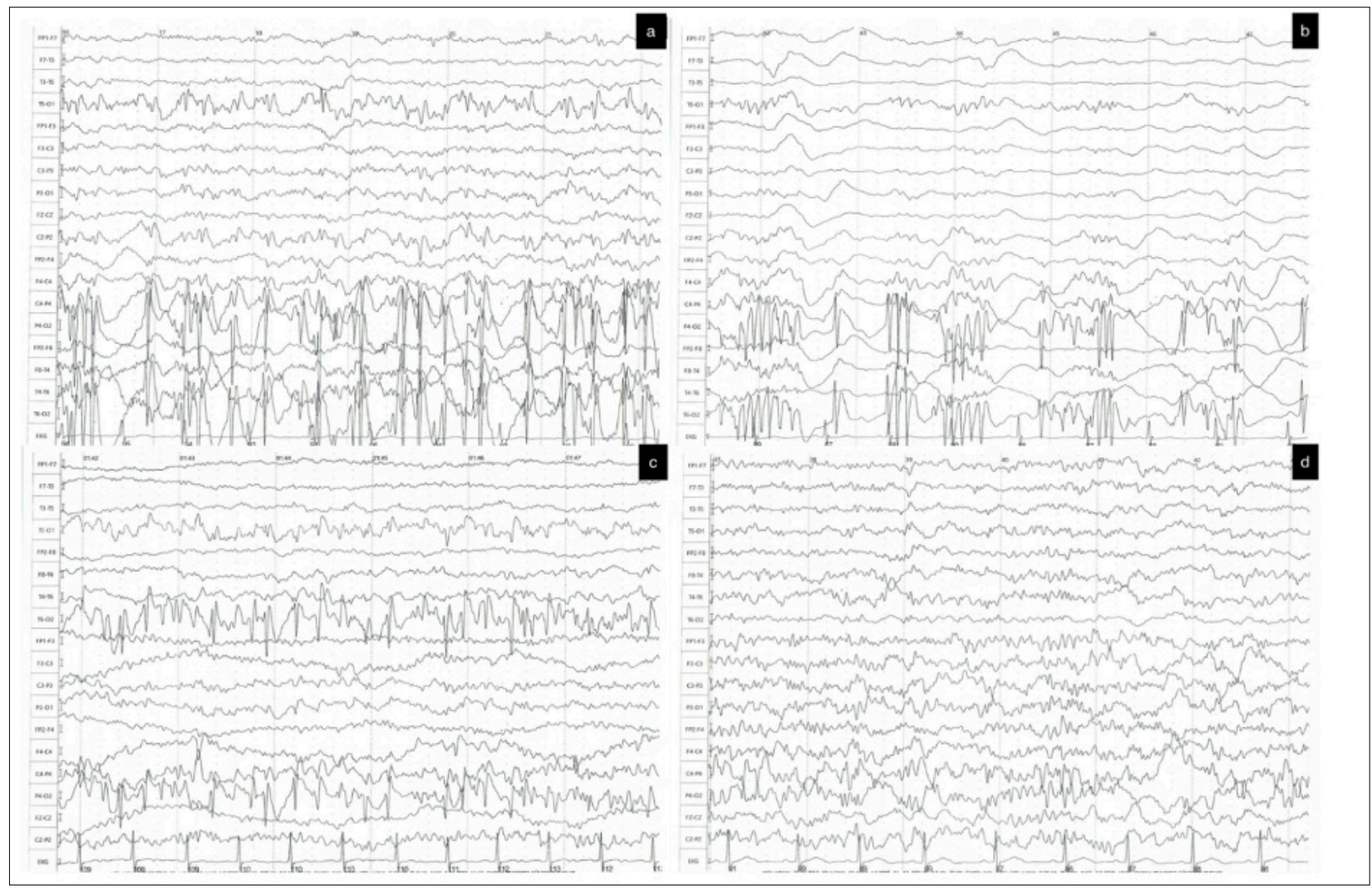

Figure 1. EEG pattern changes of patient 1: a) Convulsive status epilepticus, constant right parietooccipital epileptic activity. b)Epileptic activity after thiopental administration. c)Epileptic activity after ketamine administration. d)Normal EEG pattern after memantine treatment
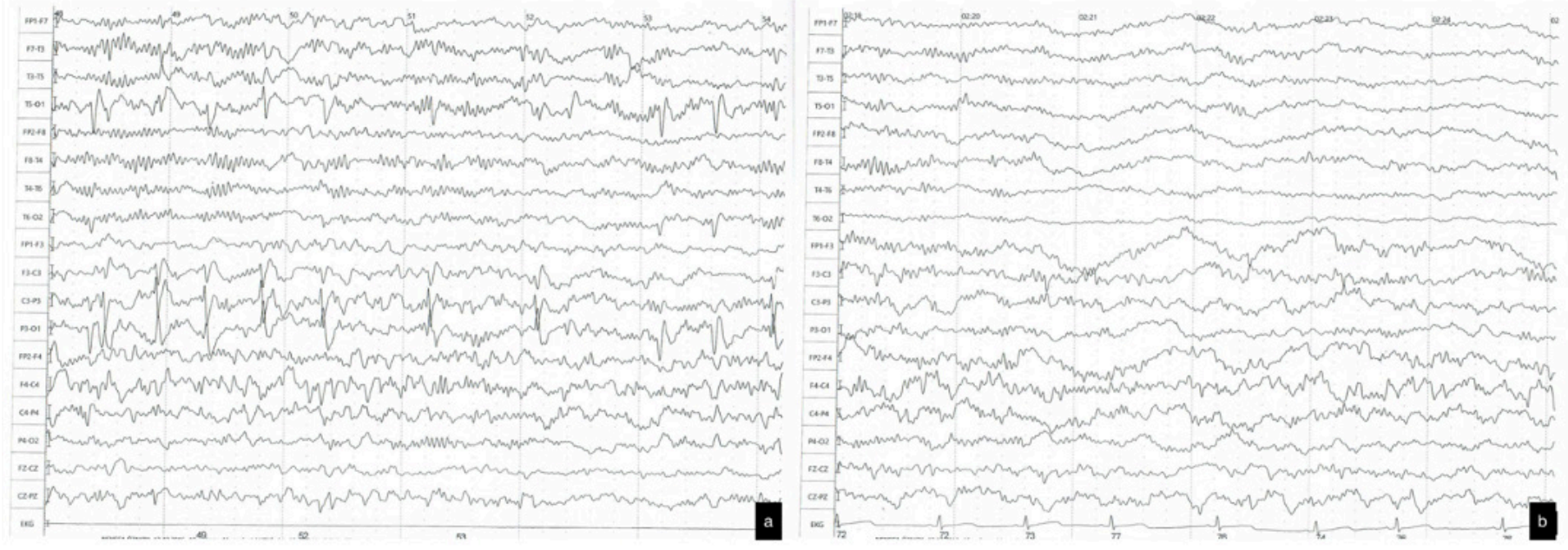

Figure 2. EEG pattern changes of patient 2: a) Intractable epilepsy left parietooccipital epileptic activity. b)Normal EEG findings after memantine treatment.

temporal epileptic activity. His seizure frequency was reduced to one in four or five months (Table 2).

\section{Case 4}

Patient 4 was a 7.5-year-old boy who was born at term. His prenatal period was uneventful. He was the third child of nonconsanguineous healthy parents, and his two elder brothers were healthy. Mental retardation was seen in two members of the extended family. His first seizure was multifocal clonic type and occurred on the 16th day of life. The first EEG study was normal. Phenobarbital was initiated as anticonvulsant therapy. He had a second multifocal clonic seizure at age 6 months and levetiracetam was added to his therapy. By the age of 8 months, he had the third seizure, the same as in previous seizures. Anticonvulsant therapy was rearranged as a higher dose of levetiracetam monotherapy until 1 year of age 
when he experienced agitation and valproic acid monotherapy was initiated. All EEG studies were normal until age 3.5 years. He had a tonic seizure, and parietooccipital epileptic activity was detected on an EEG study for the first time.

He could sit unsupported and walk independently at the appropriate age, but his speech development was delayed. A physical examination was normal except for language skills.

Metabolic studies: ammonia, plasma, and urine amino acid analysis, long-chained fatty acid analysis, urine organic acid analysis, lactate, pyruvate, tandem mass spectrometry, vitamin B12, and folic acid were within normal limits. Brain MRI and MR spectroscopy were normal.

The patient presented to or clinic at age 4.5 years. His anticonvulsant therapy at that time was valproic acid and an EEG study showed parietooccipital epileptic activity. He had seizures once per year for 2 years. WES analysis was conducted and a novel, heterozygous GRIN2D c.58_60delCTG variant was detected. The GRIN2D (NM_000836.4, p.Leu20del) variant was evaluated according to the ACMG criteria and classified as likely pathogenic because it was located in a mutational hot spot and/or critical and well-established functional domain (e.g., the active site of an enzyme) without benign variation (PM1 criteria), not found in gnomAD genomes (PM2 criteria), protein length changes as a result of in-frame deletions/insertions in a non-repeat region or stop-loss variants (PM4 criteria), and compatible with the patient's clinic (PP4 criteria).

Follow-up EEG studies showed bilateral temporoparietal epileptic activity. Memantine was not initiated, and anticonvulsant therapy remained as valproic acid because his seizure frequency was low. His last seizure was 6 months ago. He has been receiving speech therapy rehabilitation (Table 2).

\section{DISCUSSION}

Developmental and epileptic encephalopathies (DEEs) represent a clinically and genetically heterogeneous group of age-dependent neurologic disorders characterized by the onset of refractory seizures in infancy or early childhood.
Affected individuals have delayed psychomotor development or developmental regression, particularly after the onset of seizures. DEE incorporates the previous grouping of "early infantile epileptic encephalopathies (EIEE)." There are 89 described DEEs in the literature and the phenotype is also observed in other genetic disorders, including GLUT1 deficiency syndrome, glycine encephalopathy, Aicardi-Goutières syndrome, and in males with MECP2 mutations. [10] NMDAR mutations are associated with DEEs; DEE27 is caused by a mutation in the GRIN2B gene, DEE46 is caused by a mutation in the GRIN2D gene. $[3,4,11]$

We described four patients with DEE and de novo variants in the GRIN2D gene. Age at onset of epileptic encephalopathy is generally before 2 years of age.[12] Camp et al. reported a median age of onset of 6.5 months for GRIN2D DEE.[3] Three of our patients had seizures within the first month of life and patient 3 had their first seizure rather late, at age 4 years.

Early studies of NMDAR genes were about schizophrenia and autism spectrum disorder. In 2011, Tarabeux et al. showed neuropsychiatric disease's relation to GRIN1, GRIN2A, GRIN2B, and GRIN2D families.[1] Camp et al. found that $31 \%$ of patients displayed autistic-like features and behaviors accompanying epilepsy.[3] None of our patients had autistic-like features or behaviors. Developmental delay and intellectual disability are part of the clinical characteristics, but affected individuals show varying severity, as in our patients; patient 3 was independent in his daily life, but patient 2 was bedbound.

In epileptic encephalopathies, particularly spasm, and tonic, clonic, myoclonic, atonic, atypical absence seizures can be seen in infancy. Over time, changes can be seen between these seizure types.[10,13] Multifocal clonic seizures and spasms are prominent in GRIN2D encephalopathy.[3] Multifocal clonic seizures were more common in our patients. With age, as in other epileptic encephalopathies, our patients also developed atonic, tonic, and atypical absence seizures. In GRIN2D encephalopathy, unlike other epileptic encephalopathies, ocular flutter, tongue movement, and body tremor, which occur out of 
seizures and increase during seizures, have been reported.[3]

Hypsarrhythmia and multifocal epileptiform abnormalities are prominent EEG patterns for epileptic encephalopathies in infancy. EEG patterns can change into multifocal/focal epileptiform abnormalities, Lennox-Gastaut syndrome, and epileptic encephalopathy with continuous spike-and-wave during sleep (CSWS) over time.[13,14] A limited case series about GRIN2D encephalopathy revealed a multifocal epileptiform abnormality, hypsarrhythmia, focal spike-wave activity, and paroxysmal fast activity patterns on EEG.[3] One of our patients had a multifocal epileptiform abnormality and one had a hypsarrhythmia pattern in infancy. Different from the literature, two patients had normal EEG patterns in infancy. Patients 1 and 2 developed bilateral parietooccipital epileptiform activity and patient 3 developed bilateral occipital epileptiform activity later in life. Occipital epileptiform activity is mainly seen in childhood epilepsy with occipital paroxysm (CEOP) and CEOP is classified as benign childhood epilepsy. Li et al. reported a poor prognosis of occipital epileptiform activity in GRIN2D encephalopathy.[4] Although cerebral atrophy, cerebellar atrophy, and cortical atrophy were frequently mentioned in previous studies, no specific MRI findings were reported in GRIN2D mutation. [3,15]

Specific treatment options are available for some of the genetic epileptic encephalopathies; pyridoxine dependent epilepsy (PDE) caused by an ALDH7A1 genetic defect (PDE-ALDH7A1), Menkes disease, pyridox (am)ine-5-phosphate oxidase (PNPO) deficiency, cobalamin $G$ deficiency, severe methylenetetrahydrofolate reductase (MTHFR) deficiency, glucose transporter 1 (GLUT1) deficiency, glycine encephalopathy, and pyruvate dehydrogenase complex (PDHC) deficiency, uridine responsive CAD deficiency, cerebral folate deficiency, creatinine deficiency syndrome, DEND syndrome, serine biosynthesis defect, biotinidase deficiency, nonketotic hyperglycinemia, KCNQ2 encephalopathy, KCNT1-related epilepsy, and BH4 deficiency (Table 1).[16-18] Memantine is prominently used in cognitive impairments such as Alzheimer's disease.[19] With its effect on NMDARs, studies have been conducted for the use of memantine as an AED in GRIN mutations. $[4-6,20]$ Memantine was used in patient 1 with refractory status, patient 2 with intractable seizures, and patient 3 with frequent seizures. Both patients 1 and 2 remained seizure-free, and the seizure frequency of patient 3 was reduced.

Limitations of the study

Our study has several limitations, mainly related to the study population size. The number of patients meeting the inclusion criteria was small because it was a single center study. In our opinion, it would be more effective to identify new variants and define the phenotype-genotype characteristics of these variants in a multi-center study.

\section{CONCLUSION}

Occipital epilepsy is usually benign, but with developmental delay, epileptic encephalopathy must be considered. Genetic studies are important for epileptic encephalopathy because specific therapies for targeted gene mutations are available for some epileptic encephalopathies. Genotypephenotype correlation studies are necessary to gain more information about the subject.

Conflict of Interest: The author has no conflict of interest related to this article.

Funding sources: The author declared that this study has received no financial support

Ethics Committee Approval: Antalya Research and Training Hospital Ethics Committee (Date: 04.03.2021 number: 1/44).

Peer-review: Externally and internally peer reviewed.

\section{REFERENCES}

Tarabeux J Kebir O, Gauthier J, Hamdan FF, Xiong L, Piton A, et al. Rare mutations in $\mathrm{N}$-methyl-D-aspartate glutamate receptors in autism spectrum disorders and in N-methyl-D-aspartate glutamate receptors in autism spectrum disorders and
schizophrenia. Translational Psychiatry 2011;1. https://doi.org/10.1038/tp.2011.52. Perszyk RE, DiRaddo JO, Strong KL, Low CM, Ogden KK, Khatri A, et al. GluN2D-containing N-methyl-D-aspartate receptors mediate synaptic transmission in hippocampal interneurons and regulate interneuron activity. Molecular Pharmain hippocampal interneurons and regulate interneuron activity. Mo
cology 2016;90:689-702. https://doi.org/10.1124/mol.116.105130.

3. Camp CR, Yuan H. GRIN2D/GluN2D NMDA receptor: Unique features and its contribution to pediatric developmental and epileptic encephalopathy. European Journal of Paediatric Neurology 2020;24:89-99. https://doi.org/10.1016/j. pean Journal of Paer
ejpn.2019.12.007.

4. Li D, Yuan H, Ortiz-Gonzalez XR, Marsh ED, Tian L, McCormick EM, et al. GRIN2D Recurrent De Novo Dominant Mutation Causes a Severe Epileptic Encephalopathy Recurrent De Novo Dominant Mutation Causes a Severe Epileptic Encephalopathy
Treatable with NMDA Receptor Channel Blockers. American Journal of Human Genetics 2016;99:802-16. https://doi.org/10.1016/j.ajhg.2016.07.013.

5. Pierson TM, Yuan H, Marsh ED, Fuentes-Fajardo K, Adams DR, Markello T, et al. GRIN2A mutation and early-onset epileptic encephalopathy: personalized therapy with memantine. Annals of Clinical and Translational Neurology 2014;1:190-8. https://doi.org/10.1002/acn3.39.

6. Marimuthu P, Varadarajan S, Krishnan M, Shanmugam S, Kunjuraman GR, Ravin- 
der $\mathrm{J}$, et al. Evaluating the efficacy of memantine on improving cognitive functions in epileptic patients receiving anti-epileptic drugs: A doublo-blind placebo-controlled clinical trial (Phase IIb pilot study). Annals of Indian Academy of Neurology trolled clinical trial (Phase Illb pilot study). Annals of Indian Academy of Neurology

7. McMullin D. Epi4K: Gene discovery in 4,000 genomes. Epilepsia 2012;53:1457-67. https://doi.org/10.1111/j.1528-1167.2012.03511.x.

8. Richards S, Aziz N, Bale S, Bick D, Das S, Gastier-Foster J, et al. Standards and guidelines for the interpretation of sequence variants: A joint consensus recommendation of the American College of Medical Genetics and Genomics and the Association for Molecular Pathology. Genetics in Medicine 2015;17:405-24. https:// doi.org/10.1038/gim.2015.30.

9. Berg AT, Berkovic SF, Brodie MJ, Buchhalter J, Cross JH, van Emde Boas W, et al. Revised terminology and concepts for organization of seizures and epilepsies: Report of the ILAE Commission on Classification and Terminology, 2005-2009. Epilepsia 2010;51:676-85. https://doi.org/10.1111/j.1528-1167.2010.02522.x.

10. McTague A, Howell KB, Cross JH, Kurian MA, Scheffer IE. The genetic landscape of the epileptic encephalopathies of infancy and childhood. The Lancet Neurology 2016;15:304-16. https://doi.org/10.1016/S1474-4422(15)00250-1.

11. Lemke JR, Hendrickx R, Geider K, Laube B, Schwake M, Harvey RJ, et al. GRIN2B mutations in west syndrome and intellectual disability with focal epilepsy. Annals of Neurology 2014;75:147-54. https://doi.org/10.1002/ana.24073.

12. Ware TL, Huskins SR, Grinton BE, Liu YC, Bennett MF, Harvey M, et al. Epidemiology and etiology of infantile developmental and epileptic encephalopathie in Tasmania. Epilepsia Open 2019;4:504-10. https://doi.org/10.1002/epi4.12350.

13. Jain P, Sharma S, Tripathi M. Diagnosis and Management of Epileptic Encephalopathies in Children. Epilepsy Research and Treatment 2013;2013:1-9. https://doi. org/10.1155/2013/501981.

14. von Deimling M, Helbig I, Marsh ED. Epileptic Encephalopathies-Clinical Syndromes and Pathophysiological Concepts. Current Neurology and Neuroscience Reports 2017;17. https://doi.org/10.1007/s11910-017-0720-7.

15. XiangWei W, Kannan V, Xu Y, Kosobucki GJ, Schulien AJ, Kusumoto H, et al. Heterogeneous clinical and functional features of GRIN2D-related developmental and epileptic encephalopathy. Brain 2019;142:3009-27. https://doi.org/10.1093/brain/ awz232.

16. Mercimek-Mahmutoglu S, Patel J, Cordeiro D, Hewson S, Callen D, Donner EJ, et al. Diagnostic yield of genetic testing in epileptic encephalopathy in childhood. Epilepsia 2015;56:707-16. https://doi.org/10.1111/epi.12954.

17. Zhou L, Deng J, Stenton SL, Zhou J, Li H, Chen C, et al. Case Report: Rapid Treatment of Uridine-Responsive Epileptic Encephalopathy Caused by CAD Deficiency. Frontiers in Pharmacology 2020;11. https://doi.org/10.3389/fphar.2020.608737.

18. Assi L, Saklawi Y, Karam PE, Obeid M. Treatable Genetic Metabolic Epilepsies. Current Treatment Options in Neurology 2017;19. https://doi.org/10.1007/s11940017-0467-0.

19. Tampi R, van Dyck C. Neuropsychiatric Disease and Treatment 2007:3(2) Memantine: efficacy and safety in mild-to-severe Alzheimer's disease. doi:10.2147/ nedt.2007.3.2.245.

20. Aman MG, Findling RL, Hardan AY, Hendren RL, Melmed RD, Kehinde-Nelson O, et al. Safety and efficacy of memantine in children with autism: Randomized, placebo-controlled study and open-label extension. Journal of Child and Adolescent Psychopharmacology 2017;27:403-12. https://doi.org/10.1089/cap.2015.0146.

\begin{tabular}{|l|l|}
\hline Author / ORCID & Authorship Contrubition \\
\hline $\begin{array}{l}\text { Muhammet Gultekin Kutluk } \\
\text { 0000-0002-3631-068X }\end{array}$ & $\begin{array}{l}\text { Consept, design, materials, } \\
\text { data collection, analysis, } \\
\text { interpretation, literature search, } \\
\text { manuscript writing, final } \\
\text { approval, critical review }\end{array}$ \\
\hline $\begin{array}{l}\text { Nadide Cemre Randa } \\
0000-0003-1239-6703\end{array}$ & $\begin{array}{l}\text { Consept, analysis, literature } \\
\text { review, manuscript writing, final } \\
\text { approval, critical review }\end{array}$ \\
\hline
\end{tabular}

